\title{
Short communication: New report of Aedes albopictus in Souk Ahras, Northeast Algeria
}

\author{
KAOUTHER HAMAIDIA ${ }^{1,2 v}$, NOUREDDINE SOLTANI ${ }^{2}$ \\ ${ }^{1}$ Department of Biology, Faculty of Nature and Life Sciences, Mohamed Cherif Messaadia University. Souk Ahras, 41000, Algeria. \\ •email: k.hemaidia@univ-soukahras.dz \\ ${ }^{2}$ Laboratory of Applied Animal Biology, Department of Biology, Faculty of Sciences, University Badji Mokhtar of Annaba. Annaba, 23000, Algeria
}

Manuscript received: 31 March 2021. Revision accepted: 25 June 2021.

\begin{abstract}
Hamaidia K, Soltani N. 2021. Short communication: New report of Aedes albopictus in Souk Ahras, Northeast Algeria. Biodiversitas 22: 2901-2906. The present paper reports the occurrence of Aedes albopictus (Skuse), an aggressive Asian tiger mosquito in the city of Souk-Ahras (Northeast of Algeria). A "26 April" estate' inhabitants (Souk-Ahras province) have reported unusual daytime bites by a striped mosquito. On early September 2020, an intensive field inspection was carried out for potential mosquito breeding sites in the locations around the city. A total of 105 specimens (8 larvae, 24 pupae and 73 adults) of Ae. albopictus were collected in a pile of old tyres in a residential garden. After previous records of this species in Algeria, this is the first evidence of its presence in Souk-Ahras province, and the findings enhance combined public participation with professional validation in surveillance of vector borne-diseases programs with emphasis on the need for sensitising citizens about controlling this important vector.
\end{abstract}

Keywords: Aedes albopictus, Algeria, first record, invasive mosquito, Souk-Ahras

\section{INTRODUCTION}

The Asian tiger mosquito, Aedes albopictus (Skuse) (Diptera: Culicidae), is an invasive mosquito geographically restricted to parts of the Asia-Pacific region (Medlock et al. 2015). However, the high tolerance to this relatively thermophilic mosquito species showed an important spread possibility in several climatically different regions (Kamal et al. 2018; Tippel et al. 2019) showing survival suitability for European and American countries. Climate change represents along with urbanization and globalization, the major guiding for this geographic expansion (Poinsignon et al. 2019; Lwande et al. 2020).

Apart from causing discomfort with its daytime bites, the major concern of Ae. albopictus emergence is its ability to transmit several viruses (Amraoui et al. 2019; Bohers et al. 2020). This species has been implicated as a vector of chikungunya (Honório et al. 2019), dengue (Ferreira-deLima et al. 2020), yellow fever (Kamgang et al. 2019) and Zika (McKenzie et al. 2019; Bohers et al. 2020) viruses. Many southern European countries suffered from several vector borne diseases with Aedes albopictus as a main vector. Recently, native chikungunya was reported in France (Calba et al. 2017; Franke et al. 2019) and Italy (Venturi et al. 2017). Moreover, the dengue and Zika virus (Calba et al. 2017; Vasqueza et al. 2018) infection outbreak was detected in southern France, fortunately with low to medium-low risk perception (Le Tyrant et al. 2019).

Huge efforts to mitigate the viruses' emerging public health threat have been made at different levels (individual, environmental and household), especially by improving biomedical research to prevent infectious vector-borne diseases (Chan et al. 2020). Unfortunately, the dynamics of arbovirus vectors such as Ae. albopictus are weakly understood (Tedjou et al. 2020).

The focus of most researches was on pathogens (viruses, etc.) and their effects on humans, much less on their arthropod host, while the spread of these diseases strongly depends on the spatiotemporal evolution of vector populations. In medical entomology, the domestication phenomenon of vector borne-diseases was reported as an adaptation throughout their history with humans (Powell and Tabachnick 2013). Recently, it has been proven that the spread of Ae. albopictus in new areas following its introduction could be explained in relation with human movement models (Kraemer et al. 2019) and classified as potential bridge vectors of arboviruses (Pereira-dos-Santos et al. 2020). Adaptation of Ae. albopictus for urban areas was recently reported (Muhammad et al. 2020).

Although several studies have been undertaken over the past two decades on the biodiversity of the eastern Algerian mosquito-fauna (Messai et al. 2010; Bouabida et al. 2012; Benhissen et al. 2014; Lounaci et al. 2014; Hamaidia et al. 2016; Merabti et al. 2017; Benmalek et al. 2018; Hamaidia and Bershi 2018; Hafsi et al. 2021), there was no report on Ae. albopictus, while it was previously listed in a few Central Algeria regions (Benallal et al. 2019).

In order to carry out an effective monitoring program including the ordering of mosquito vector species, we suggest integrated surveillance tools, based on novel community-implication such as Mosquito Alert System (Eritja et al. 2019). At University of Souk-Ahras, a new project (No. D01N01UN410120210001) has been established not only for the surveillance of indigenous and newly emerged mosquito species, but the exploration of potential human and environmental pressures affecting 
their distribution and dynamics as well. The main objective was to create an efficient combination between citizensourced data and traditional epidemiological resources and perform effective control operations on the one hand. On the other hand, new sustainable control strategies will be performed against mosquitoes with botanical products (Bouzidi et al. 2020; Draouet et al. 2020).

\section{MATERIALS AND METHODS}

\section{Study area}

The region of Souk-Ahras (Northeast Algeria) is a mountainous region known for its agricultural nature, its dense forest cover and several rivers flowing through it (Figure 1). It contains rural, peri-urban and urban areas. According to its climatic conditions, this area is characterised by a sub-humid climate with a long wet season (Tlidjane et al. 2019; Derdous et al. 2020) with a mean temperature of $15.33^{\circ} \mathrm{C}$ and an annual rainfall of $114.62 \mathrm{~mm}$. '26 April' estate inhabitants in Souk-Ahras province $\left(36^{\circ} 17^{\prime} 24.2^{\prime \prime} \mathrm{N} 7^{\circ} 56^{\prime} 33.6 " \mathrm{E} 653 \mathrm{~m}\right)$ (Figure 2) have reported through phone calling unusual daytime bites during the past three months (since June 2020) by a nontypical striped mosquito.

After obtaining verbal consent from householders in some locations around this city, an intensive field examination from September $10^{\text {th }}$ to $20^{\text {th }}, 2020$ was carried out for potential mosquito breeding sites. The target garden has displayed distinct characteristics; it is shady, well vegetated and wet, and it is located within an urban area, far about $500 \mathrm{~m}$ from a $30,000 \mathrm{~m}^{2}$ forest cover.

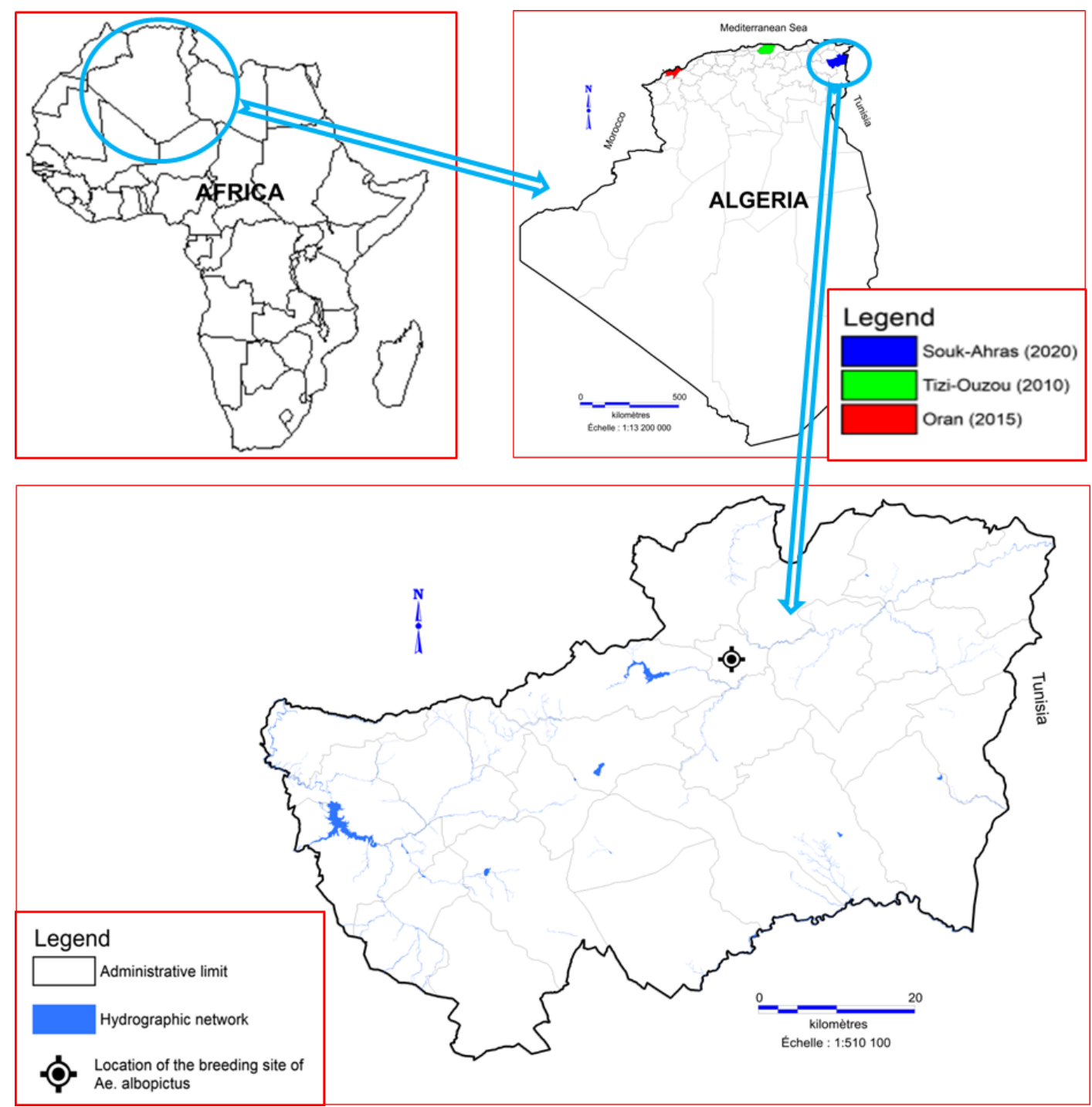

Figure 1. Location of Ae. albopictus first detections in Mediterranean coast (realized with Mapinfo Pro 12.0, 2021) 

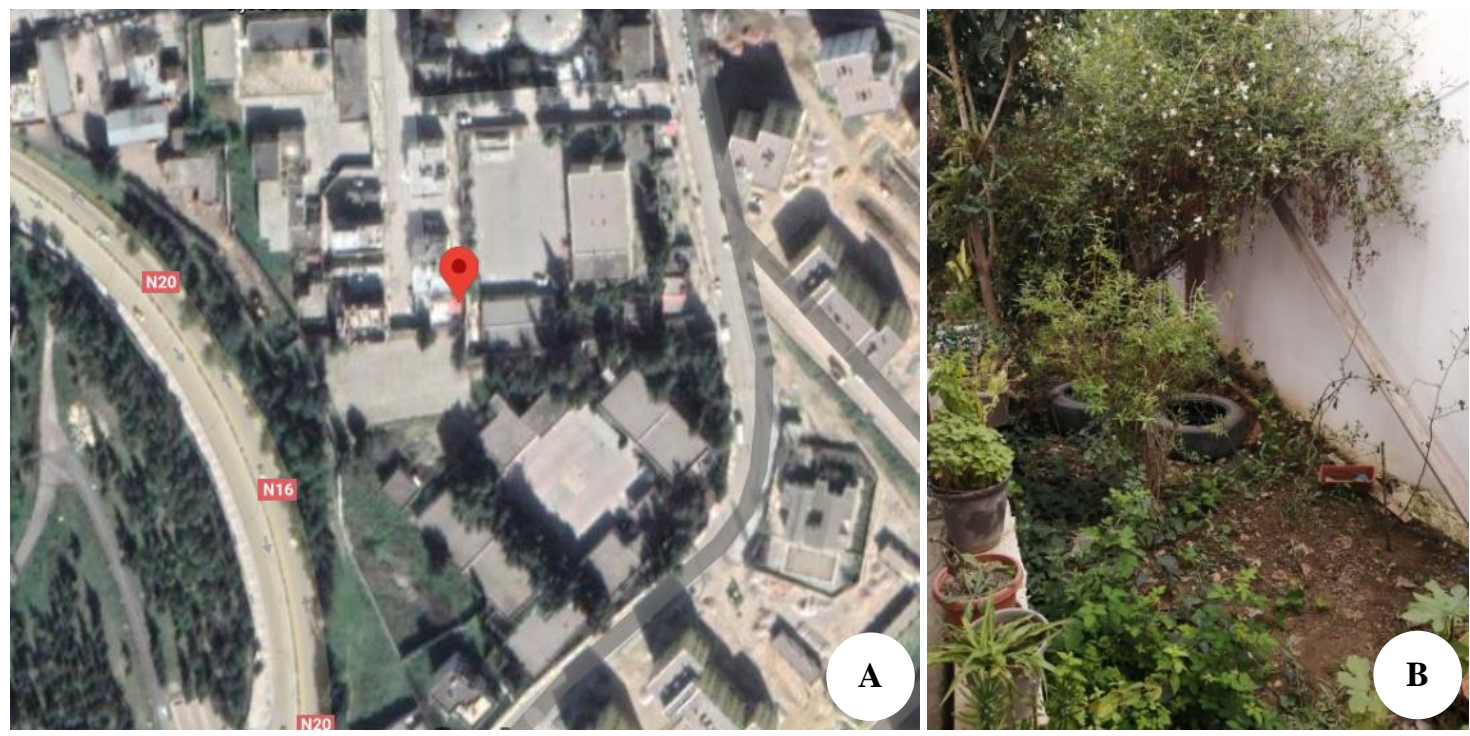

Figure 2. Breeding site of Ae. albopictus in Souk-Ahras (Algeria): A. Google-Earth; B. Residential garden

\section{Mosquito collection}

Twenty residential properties were checked during this survey where all kinds of artificial water containers, flowerpots, reservoirs, basements, wheelbarrows and construction containers have been surveyed. Immature stages (larvae and pupae) were collected using a dipper, while sampling of resting adults was carried out with manual aspirator consisting of a silicone tube, a mouth piece, a mesh and a glass tube. A total of 105 individuals (8 larvae, 24 pupa and 73 adults) were collected. The immature stages (larvae and pupae) were maintained in their breeding water site in the insectarium of laboratory of Applied Animal Biology (Faculty of Sciences, Department of Biology, University Badji Mokhtar, Annaba) until emergence of the adults. The rearing cage $\left(40 \mathrm{~cm}^{3}\right)$ with a wooden frame was covered with mesh allowing excellent transparency, and allowed access through the $15 \mathrm{~cm}$ sleeve opening. Adults were then identified using the morphological key by Schaffner et al. (2001).

\section{RESULTS AND DISCUSSION}

Aedes albopictus (Skuse, 1894) (Diptera: Culicidae) is an invasive mosquito native from Southeast Asia (Lizuain et al. 2019). It is best known as a vector of several viruses of public health significance (Bohers et al. 2020; Ferreirade-Lima et al. 2020; Vega-Rúa et al. 2020; Vega-Rúa et al. 2020) such as dengue, chikungunya, and Zika. There were a recent series of outbreaks of these diseases around the world (Calba et al. 2017; Venturi et al. 2017; Vasqueza et al. 2018; Franke et al. 2019). Aedes albopictus is wellestablished in southern European countries (Balaska et al. 2020). Italy seems to be the origin of its recent spread increasing rate in Europe (Kraemer et al. 2019). Also, recent arboviral outbreaks were more concentrated in urban areas in West Africa (Buchwald et al. 2020).
This remarkable invasion was due in the first place to its great ecological plasticity (Benelli et al. 2020; Kramer et al. 2021), especially by dry-resistant eggs easily transportable through used tires and other containers (Kamal et al. 2018). Especially that high invasion of Aedes mosquitoes in these artificial habitats was reported (Bennett et al. 2019; Lizuain et al. 2019; Malla et al. 2019; Wilke et al. 2019; Dallimore et al. 2020). Moreover, expansion of suitable vector habitats was probably the key factor caused by climate changes (Khan et al. 2020; Echeverry-Cárdenas et al. 2021). It was reported that this invasive vector appeared to have a high cold tolerance (Tippelt et al. 2019). In Algeria, the establishment and distribution of the Ae. albopictus is still unknown. This lack of information about its dynamic distribution restricted establishment of risk maps (Ducheyne et al. 2018; Monaghan et al. 2019). Thus, it is crucial to better understand the current distributions for effective surveillance programs and diseases risk management. So, this emergency plan needs to make more collections in other surrounding regions in both indoor and outdoor places.

Only few occasional detections of Ae. albopictus in the Algerian coast have been mentioned previously. In 2010, one invasive mosquito female had initially been captured in a stable in Tizi-Ouzou (Larabaa Nath Irathen locality) (Izri et al. 2011). However, this species had not been found again until 2014 through an updated mosquito list in Illoula Oumalou village (Tizi-Ouzou province), where two adult specimens of this same species were recorded (Lafri et al. 2014). This second locality is situated $40 \mathrm{~km}$ to the east of the first village.

In 2015, Ae. albopictus reappeared in the west of the country, in Oran in the seaside resort of Ain Turk, where all developmental stages (from egg to adult) were found during two consecutive years, which means that this species has settled well (Benallal et al. 2016). In addition to these occasional records in the Mediterranean coast, 
Ae. albopictus larvae and adults were first collected in Rabat (Morocco) on early September 2015 (Bennouna et al. 2017) and in Tunisia in 2018 (Bouattour et al. 2019). Unlike these three detections of Ae. albopictus between 2010 to 2015, there has been no record in eastern Algeria until now, suggesting that it has recently successfully invaded several new Algerian areas (Benallal et al. 2019). With these sightings of Ae. albopictus in various regions of Algeria, there would be a necessity to use ecological niche models as potential identifiers of invasion in new areas and therefore, subsequently, identification and collections in those new areas.

Citizens play a key role in detection of this mosquito, as well as in its spread and control. A report of unusual daytime bites by a striped mosquito was made by residents from Souk-Ahras province (eastern Algeria). On early September 2020, a total of 105 specimens of different development instars of Ae. albopictus were collected after an intensive field inspection in twenty residential properties from a residential shady vegetated garden in a pile of old tyres (Figure 2). After specimens identification as Ae. albopictus (Figure 3), all artificial containers were inspected as potential larval sites and they were immediately eliminated in order to avoid the further spreading of this mosquito.

Aedes albopictus adults are distinguished by a black scutum with a continuing median longitudinal white stripe along the thorax (Figure 3-B). They are also recognized by their black legs with distinct white basal scales on each tarsal segment (Figure 3-D). Our findings suggest the presence of Ae. albopictus in Souk-Ahras. Aedes albopictus was caught in three habitat types; rural, periurban and urban areas (Mayi et al. 2020).

Aedes albopictus prefers shady areas where it rests in shrubs near the ground (Kamgang et al. 2019). Several recent studies revealed a high infestation of invasive Aedes mosquitoes in used tires in several countries (Bennett et al. 2019; Lizuain et al. 2019; Malla et al. 2019; Wilke et al. 2019; Dallimore et al. 2020). Tires represent a perfect refuge of immature mosquitoes from predators and the rubber guarantees efficient thermal insulation (Wilke et al. 2019). Aedes albopictus is characterized by its eclectic feeding behavior, and its ecological preference to urban and peri-urban vegetated settings for feeding and resting (Lounibos and Kramer 2016). This kind of habitats was found to improve adult fitness and reproductive success (Muhammad et al. 2020).

Unlike Ae. aegypti spread which is characterized by long distance importations, Ae. albopictus has expanded more along the fringes of its distribution (Kraemer et al. 2019). Known that the Asian tiger mosquito is well established in Tunisia (Bouattour et al. 2019), it was expected to detect it in Souk-Ahras (Tunisian border). Especially since Souk-Ahras province is considered as a transit point for various export traffic. Alarmingly, it was demonstrated experimentally that Ae.albopictus Tunisian strain was competent to transmit chikungunya, Zika and dengue viruses (Bohers et al. 2020). Aedes albopictus is well adapted for specific urban settings. Urbanization increases adult survivorship and fecundity (Muhammad et al. 2020). The most reliable method to predict the spread and establishment of new mosquito species is the systematic surveillance (Schoener et al. 2019). Fortunately, the low abundance of Ae. aegypti in our study area could make it easier to control. But, first record could probably mean its establishment anywhere, so monitoring of this species is recommended even at this level. Newly emerged vector distribution and spread maps are required to carry out effective surveillance strategies and to improve current vector control and surveillance.

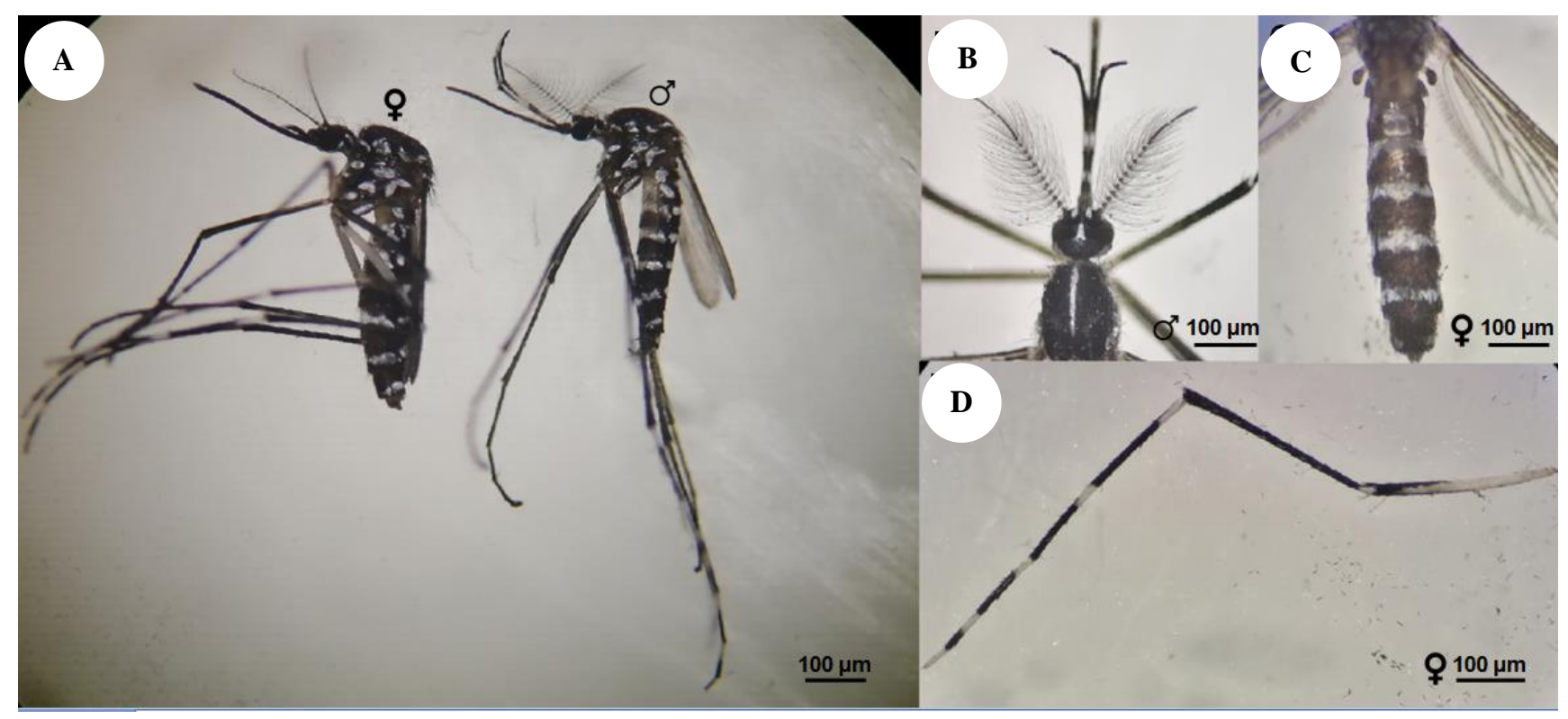

Figure 3. Aedes albopictus. A. Adults; B. Thorax; C. Abdomen; D. Third leg 
Our results highlight the effectiveness of 'passive surveillance' for tracking invasive mosquitoes involving citizens. In response to this new detection in northeastern Algeria of Ae. albopictus, it is strongly recommended to inform the public about preventive procedures to delay its spread and development, especially because of its quick adaptation in urban areas (Muhammad et al. 2020). Further investigations are requested to assess the capacity of $A e$. albopictus in Arbovirus transmission to more focus on preventive strategies by national public health authorities.

\section{ACKNOWLEDGEMENTS}

The authors are grateful to the citizens of 26 April residence (Souk-Ahras, Algeria) for their collaboration. Thanks to Dr. Benabdalah Necereddine (Department of Foreign Languages, Faculty of Letters and Languages, Mohamed Cherif Messaadia University, Souk-Ahras, Algeria) for his diligent proofreading of this short communication. This research was supported by the Algerian Fund for Scientific Research of Algeria (Laboratory Applied Animal Biology to N. Soltani) and by PRFU Project to Dr. K. Hamaidia No D01N01UN410120210001.

\section{REFERENCES}

Amraoui F, Ben AW, Madec Y, Faraj C, Himmi O, Btissam A, Sarih M, Failloux A-B. 2019. Potential of Aedes albopictus to cause the emergence of arboviruses in Morocco. PLoS Neglect Trop Dis 13 (2): e0006997. DOI: 10.1371/journal.pntd.0006997.

Balaska S, Fotakis EA, Kioulos I, Grigoraki L, Mpellou S, Chaskopoulou A, Vontas J. 2020. Bioassay and molecular monitoring of insecticide resistance status in Aedes albopictus populations from Greece, to support evidence-based vector control. Parasit Vectors 13: 328. DOI: 10.1186/s13071-020-04204-0.

Benallal KE, Garni R, Bouiba L, Harrat Z. 2019. First detection of Aedes (Stegomyia) albopictus (Diptera: Culicidae) in Algiers, the Capital City of Algeria. J Arthropod Borne Dis 13 (4): 420-425. DOI: 10.18502/jad.v13i4.2240.

Benallal K, Allal-Ikhlef A, Benhamouda K, Schaffner F, Harrat Z. 2016. First report of Aedes (Stegomyia) albopictus (Diptera: Culicidae) in Oran, west of Algeria. Acta Trop 164: 411-413. DOI: 10.1016/j.actatropica.2016.09.027.

Benhissen S, Habbachi W, Masna F, Mecheri H, Ouakid ML, Bairi A. 2014. Inventory Culicidae dry lands: The case of Oasis Ouled-Djella (Biskra, Algeria). Revue El Wahat pour les recherches et les Etudes 7: 86-91.

Benmalek L, Bendali-Saoudi F, Soltani S. 2018. Inventory and distribution of mosquitoes (Diptera; Culicidae) of the Burgas lakes (Northeast Algeria). J Entomol Zool Stud 6: 838-843

Benelli G, Wilke ABB, Beier JC. 2020. Aedes albopictus (Asian Tiger Mosquito). Trends Parasitol 36 (11): 942-943. DOI: 10.1016/j.pt.2020.01.001

Bennett KL, Gómez MC, Almanza A, Rovira JR, Owen Mcmillan W, Enriquez V, Barraza E, Diaz M, Sanchez-Galan JE, Whiteman A Gittens RA, Loaiza JR. 2019. High infestation of invasive Aedes mosquitoes in used tires along the local transport network of Panama. Parasite Vectors 12: 264. DOI: 10.1186/s13071-019-3522-8.

Bohers C, Mousson L, Madec Y, Vazeille M, Rhim A, M'ghirbi Y, Bouattour A, Failloux A-B. 2020. The recently introduced Aedes albopictus in Tunisia has the potential to transmit chikungunya, dengue and Zika viruses. PLoS Neglect Trop Dis 14 (10): e0008475. DOI: 10.1371/journal.pntd.0008475.

Bouabida H, Djebbar F, Soltani N. 2012. Etude systématique et écologique des Moustiques (Diptera: Culicidae) dans la région de
Tébessa (Algérie). Entomologie faunistique - Faunistic Entomol 65: 99-103. [French]

Bouattour A, Khrouf F, Rhim A, M'ghirbi Y. 2019. First detection of the Asian tiger mosquito, Aedes (Stegomyia) albopictus (Diptera: Culicidae), in Tunisia. J Med Entomol 56 (4): 1112-1115. DOI: 10.1093/jme/tjz026.

Bouzidi O, Tine S, Hamaidia K, Tine-Djebbar F, Soltani N. 2020. Chemical composition and bioefficacy of essential oil from Bay Laurel Shrub (Laurales: Lauraceae) against Culiseta longiareolata (Macquart) (Diptera: Culicidae) larvae. J Entomol Sci 55: 262-272. DOI: 10.18474/0749-8004-55.2.262.

Bennouna A, Balenghien T, El Rhaffouli H, Schaffner F, Garros C, Gardes L, Lhor Y, Hammoumi S, Chlyeh G, Fassi FO. 2017. First record of Stegomyia albopicta (=Aedes albopictus) in Morocco: A major threat to public health in North Africa? Med Vet Entomol 31 (1): 102-106. DOI: $10.1111 /$ mve.12194.

Buchwald AG, Hayden MH, Dadzie SK, Paull SH, Carlton EJ. 2020. Aedes-borne disease outbreaks in West Africa: A call for enhanced surveillance. Acta Trop 209: 105468. DOI: 10.1016/j.actatropica.2020.105468.

Calba C, Guerbois-galla M, Franke F, Jeannin C, Auzet-caillaud M, Grard G, Pigaglio L, Decoppet A, Weicherding J, Savaill M-C, MunozRiviero M, Chaud P, Cadiou B, Ramalli L, Fournier P, Noël H, De Lamballerie X, Paty M-C, Leparc-goffart I. 2017. Preliminary report of an autochthonous chikungunya outbreak in France, July to September 2017. Euro Surveill 22 (39): 17-00647. DOI: 10.2807/1560-7917.ES.2017.22.39.17-00647.

Chan E, Sham T, Shahzada TS, Dubois C, Huang Z, Liu S, Hung K, Tse S, Kwok KO, Chung PH, Kayano R, Shaw R. 2020. Narrative review on health-EDRM primary prevention measures for vector-borne diseases. Intl J Environ Res Public Health 17 (16): 5981. DOI: 10.3390/ijerph17165981.

Dallimore T, Goodson D, Batke S, Strode C. 2020. A potential global surveillance tool for effective, low-cost sampling of invasive Aedes mosquito eggs from tyres using adhesive tape. Parasite Vectors 13 (1): 91. DOI: 10.1186/s13071-020-3939-0.

Derdous O, Bouguerra H, Tachi SE, Bouamrane A. 2020. A monitoring of the spatial and temporal evolutions of aridity in northern Algeria. Theor Appl Climatol 142 (3): 1191-1198. DOI: 10.1007/s00704-02003339-5.

Draouet C, Hamaidia K, Brakni A, Boutemedjet S, Soltani N. 2020. Ethanolic extracts of Borago officinalis L. affect growth, development and energy reserve profile in the mosquito Culex pipiens. J Entomol Res 44 (2): 203-210. DOI: 10.5958/0974-4576.2020.00037.7.

Ducheyne E, Tran Minh NN, Haddad N, Bryssinckx W, Buliva E, Simard F, Malik MR, Charlier J, De Waele V, Mahmoud O, Mukhtar M, Bouattour A, Hussain A, Hendrickx G, Roiz D. 2018. Current and future distribution of Aedes aegypti and Aedes albopictus (Diptera: Culicidae) in WHO Eastern Mediterranean region. Intl J Health Geogr 17: 4. DOI: 10.1186/s12942-018-0125-0.

Franke F, Giron S, Cochet A, Jeannin C, Leparc-Goffart I, de Valk H, Jourdain F, de Lamballerie X, L'Ambert G, Paty MC. 2019. Autochthonous chikungunya and dengue fever outbreak in Mainland France, 2010-2018. Eur J Public Health 29 (4): ckz186.628. DOI: 10.1093/eurpub/ckz186.628.

Echeverry-cárdenas E, López-castañeda C, Carvajal-castro JD, AguirreObando OA. 2021. Potential geographic distribution of the tiger mosquito Aedes albopictus (Skuse, 1894) (Diptera: Culicidae) in current and future conditions for Colombia. PLoS Negl Trop Dis 15 (5): e0008212. DOI: 10.1371/journal.pntd.0008212.

Eritja R, Ruiz-arrondo I, Delacour-estrella S, Schaffner F, Álvarezchachero J, Bengoa M, Puig M-Á, Melero-alcíbar R, Oltra A, Bartumeus F. 2019. First detection of Aedes japonicus in Spain: An unexpected finding triggered by citizen science. Parasite Vectors 12: 53. DOI: 10.1186/s13071-019-3317-y.

Ferreira-De-Lima VH, Andrade PDS, Thomazelli LM, Marrelli MT, Urbinatti PR, Marques DSARM, Lima-camara TN. 2020. Silent circulation of dengue virus in Aedes albopictus (Diptera: Culicidae) resulting from natural vertical transmission. Sci Rep 10: 3855. DOI: 10.1038/s41598-020-60870-1.

Hafsi N-EH, Hamaidia K, Barour C, Soltani N. 2021. A survey of Culicidae (Insecta Diptera) in some habitats in Souk-Ahras province (Northeast Algeria). Biodivers J 12 (1): 3-16. DOI: 10.31396/Biodiv.Jour.2021.12.1.3.16. 
Hamaidia H, Berchi S. 2018. Etude systématique et écologique des Moustiques (Diptera: Culicidae) dans la région de Souk-Ahras (Algérie). Entomologie Faunistique - Faunistic Entomol 71: 1-8.

Hamaidia K, Tine-djebbar F, Solatni N. 2016. Faune Culicidiennes de La Région de Souk-Ahras (Nord-Est Algérie): Répartition Spatiotemporelle et Corrélation Avec Les Facteurs du Milieu. Saarbrücken, Editions Universitaires Européennes. [French]

Honório NA, Wiggins K, Eastmond B, Câmara D, Alto BW. 2019. Experimental vertical transmission of Chikungunya virus by Brazilian and Florida Aedes albopictus populations. Viruses 11 (4): 353. DOI: 10.3390/v11040353.

Izri A, Bitam I, Charrel RN. 2011. First entomological documentation of Aedes (Stegomyia) albopictus (Skuse, 1894) in Algeria. Clinical Microbiol Infect 17 (7): 1116-1118. DOI: 10.1111/j.14690691.2010.03443.x.

Kamal M, Kenawy MA, Rady MH, Khaled AS, Samy AM. 2018. Mapping the global potential distributions of two arboviral vector Aedes aegypti and Ae. albopictus under changing climate. PLoS ONE 13 (12): e0210122. DOI: 10.1371/journal.pone.0210122.

Kamgang B, Vazeille M, Yougang AP, Tedjou AN, Wilson-Bahun TA, Mousson L, Wondji CS, Failloux AB. 2019. Potential of Aedes albopictus and Aedes aegypti (Diptera: Culicidae) to transmit yellow fever virus in urban areas in Central Africa. Emergig Microb Infect 8 (1): 1636-1641. DOI: 10.1080/22221751.2019.1688097

Khan SU, Ogden NH, Fazil AA, Gachon PH, Dueymes GU, Greer AL, $\mathrm{Ng} \mathrm{V.} \mathrm{2020.} \mathrm{Current} \mathrm{and} \mathrm{projected} \mathrm{distributions} \mathrm{of} \mathrm{Aedes} \mathrm{aegypti} \mathrm{and}$ Ae. albopictus in Canada and the U.S. Environ Health Perspect 128 (5): 057007. DOI: 10.1289/EHP5899.

Kraemer MUG, Reiner RC, Brady OJ, Messina JP, Gilbert M, Pigott DM, Yi D, Johnson K, Earl L, Marczak LB. Shirude S, Weaver ND, Bisanzio D, Perkins TA, Lai S, Lu X, Jones P, Coelho GE, Carvalho RG, van Bortel W, Marsboom C, Hendrickx G, Schaffner F, Moore CG, Nax HH, Bengtsson L, Wetter E, Tatem AJ, Brownstein JS, Smith DL, Lambrechts L, Cauchemez S, Linard C, Faria NR, Pybus OG, Scott TW, Liu Q, Yu H, Wint GRW, Hay SI, Golding N. 2019. Past and future spread of the arbovirus vectors Aedes aegypti and Aedes albopictus. Nat Microbiol 4: 854-863. DOI: 10.1038/s41564-019-0376-y.

Kramer IM, Pfeiffer M, Steffens O, Schneider F, Gerger V, Phuyal P, Braun M, Magdeburg A, Ahrens B, Groneberg DA, Kuch U, Dhima M, Müller R. 2021. The ecophysiological plasticity of Aedes aegypti and Aedes albopictus concerning overwintering in cooler ecoregions is driven by local climate and acclimation capacity. Sci Total Environ 778: 146128. DOI: 10.1016/j.scitotenv.2021.146128.

Lafri I, Bitam I, Beneldjouzi A, Ben MMH. 2014. An inventory of mosquitoes (Diptera: Culicidae) in Algeria. Soc Zool Fr 139 (1-4) 255-261.

Lounaci Z, Doumandji S, Doumandji-mitiche B, Berrouane FZ. 2014. Dipterans biodiversity of agricultural and medico veterinary interest in the marsh of Reghaia (Algeria). Intl J Zool Res 4: 71-82.

Lounibos LP, Kramer LD. 2016. Invasiveness of Aedes aegypti and Aedes albopictus and vectorial capacity for Chikungunya virus. J Infect Dis 214 (suppl 5): S453-S458.

Le TM, Bley D, Leport C, Alfandari S, Guégan J-F. 2019. Low to mediumlow risk perception for dengue, chikungunya and Zika outbreaks by infectious diseases physicians in France, Western Europe. BMC Public Health 19: 1014. DOI: 10.1186/s12889-019-7317-9.

Lizuain AA, Leporace M, Santini MS, Utgés ME, Schweigmann N. 2019 Update on the distribution of Aedes albopictus (Diptera: Culicidae) in Misiones, Argentina. Revista do Instituto de Medicina Tropical de Sao Paulo 61: e46. DOI: 10.1590/S1678-9946201961046.

Lwande OW, Obanda V, Lindström A, Ahlm C, Evander M, Näslund J, Bucht G. 2020. Globe-trotting Aedes aegypti and Aedes albopictus Risk factors for Arbovirus pandemics. Vector Borne Zoonotic Dis 20 (2): 71-81. DOI: 10.1089/vbz.2019.2486.

Malla RK, Mandal KK, Dutta M, Chandra G. 2019. An estimation of monthly propagation of dengue vector Aedes aegypti in rainwater filled tires. Intl $\mathrm{J}$ Pest Manag 66 (3): 239-242. DOI: 10.1080/09670874.2019.1616130.

Mayi MPA, Bamou R, Djiappi-tchamen B, Fontaine A, Jeffries CL, Walker T, Antonio-nkondjio C, Cornel AJ, Tchuinkam T. 2020. Habitat and seasonality affect mosquito community composition in the west region of Cameroon. Insects 11 (5): 312. DOI: 10.3390/insects11050312.

Mckenzie BA, Wilson AE, Zohdy S. 2019. Aedes albopictus is a competent vector of Zika virus: A meta-analysis. PLoS ONE 14 (5): e0216794. DOI: 10.1371/journal.pone.0216794.
Medlock J, Hansford K, Versteirt V, Cull B, Kampen H, Fontenille D, Hendrickx G, Zeller H, Van Bortel W, Schaffner F. 2015. An entomological review of invasive mosquitoes in Europe. Bull Entomol Res 105 (6): 637-663. DOI: 10.1017/S0007485315000103.

Merabti B, Lebouz I, Adamou AE, Kouidri M, Ouakid ML. 2017. Effects of certain natural breeding site characteristics on the distribution of Culicidae (Diptera) mosquito species in Southeast Algeria. Afr Entomol 25: 506-514. DOI: 10.4001/003.025.0506.

Messai N, Berchi S, Boulknafd F, Louadi K. 2010. Inventaire systématique et diversité biologique de Culicidae (Diptera: Nematocera) dans la région de Mila (Algérie). Entomologie faunistique - Faunistic Entomol 63: 203-206.

Monaghan AJ, Eisen RJ, Eisen L, Mcallister J, Savage HM, Mutebi J-P, Johansson MA. 2019. Consensus and uncertainty in the geographic range of Aedes aegypti and Aedes albopictus in the contiguous United States: Multi-model assessment and synthesis. PLoS Comput Biol 15 (10): e1007369. DOI: 10.1371/journal.pcbi.1007369.

Muhammad NAF, Abu KNF, Majid AAH, Abd Rahman A, Dieng H, Avicor SW. 2020. Biting rhythm and demographic attributes of Aedes albopictus (Skuse) females from different urbanized settings in Penang Island, Malaysia under uncontrolled laboratory conditions. PLoS ONE 15 (11): e0241688. DOI: 10.1371/journal.pone.0241688.

Pereira-dos-santos T, Roiz D, Lourenço-de-oliveira R, Paupy C. 2020. Systematic review: Is Aedes albopictus an efficient bridge vector for zoonotic arboviruses? Pathogens 9: $266 . \quad$ DOI: 10.3390/pathogens9040266.

Poinsignon A, Boulanger D, Binetruy F, Elguero E, Darriet F, Gallian P, de Lamballerie X, Charrel RN, Remoue F. 2019. Risk factors of exposure to Aedes albopictus bites in mainland France using an immunological biomarker. Epidemiol Infect 147: e238. DOI: 10.1017/S0950268819001286.

Powell JR, Tabachnick WJ. 2013. History of domestication and spread of Aedes aegypti: A review. Memorias do Instituto Oswaldo Cruz 108 (Supp11): 11-17. DOI: 10.1590/0074-0276130395.

Schaffner F, Angel G, Geoffroy B, Hervy JP, Rhaiem A, Brunhes J. 2001. Les Moustiques d'Europe. Logiciel d'Identification et d'Enseignement. Logiciel sur CD-ROM. IRD Éditions, Paris, France.

Schoener E, Zittra C, Weiss S, Walder G, Barogh BS, Weiler S, Fuehrer H-P. 2019. Monitoring of alien mosquitoes of the genus Aedes (Diptera: Culicidae) in Austria. Parasitol Res 118: 1633-1638. DOI: 10.1007/s00436-019-06287-w.

Tedjou AN, Kamgang B, Yougang AP, Wilson-Bahun TA, Njiokou F, Wondji CS. 2020. Patterns of ecological adaptation of Aedes aegypti and Aedes albopictus and Stegomyia indices highlight the potential risk of Arbovirus transmission in Yaoundé, the capital city of Cameroon. Pathogens 9: 491. DOI: 10.3390/pathogens9060491.

Tippelt L, Werner D, Kampen H. 2019. Tolerance of three Aedes albopictus strains (Diptera: Culicidae) from different geographical origins towards winter temperatures under field conditions in northern Germany. PLoS ONE. 14 (7): e0219553. DOI: 10.1371/journal.pone.0219553

Tlidjane A, Menaa M, Rebbah AC, Telailia S, Seddik S, Chefrour A, Maazi MC. 2019. Amphibian species richness and distribution in the region of Souk Ahras (Northeastern Algeria). Bulletin de la Société Zoologique de France 144 (4): 179-201.

Vasqueza V, Haddada E, Perignona A, Jaureguiberrya S, Brichlerb S, Leparc-goffartc I, Caumes E. 2018. Dengue, chikungunya, and Zika virus infections imported to Paris between 2009 and 2016: Characteristics and correlation with outbreaks in the French overseas territories of Guadeloupe and Martinique. Intl J Infect Dis 72: 34-39. DOI: $10.1016 /$ j.ijid.2018.05.007.

Venturi G, Di Luca M, Fortuna C, Remoli ME, Riccardo F, Severini F, Toma L, Del Manso M, Benedetti E, Caporali MG, Amendola A, Fiorentini C, De Liberato C, Giammattei R, Romi R, Pezzotti P, Rezza G, Rizzo C. 2017. Detection of a chikungunya outbreak in Central Italy, August to September 2017. Euro Surveill 22 (39): 1700646. DOI: 10.2807/1560-7917.ES.2017.22.39.17-00646.

Vega-rua A, Marconcini M, Madec Y, Manni M, Carraretto D, Gomulski LM, Gasperi G, Failloux A-B, Malacrida AR. 2020. Vector competence of Aedes albopictus populations for chikungunya virus is shaped by their demographic history. Comm Biol 3: 326. DOI: 10.1038/s42003-020-1046-6.

Wilke ABB, Vasquez C, Petrie W, Beier JC. 2019. Tire shops in MiamiDade County, Florida are important producers of vector mosquitoes. PLoS ONE 14 (5): e0217177. DOI: 10.1371/journal.pone.0217177. 